\title{
MAIN TRENDS OF TERRORISM IN AFRICA TOWARDS 2025
}

\section{Yoslán Silverio González ${ }^{1}$}

\section{Introduction}

In the last two decades the international relations have been altered by the impacts of terrorism which have affected different areas and captured the attention of politics and scholars all over the world. The regions of Middle East and North Africa, as well as Sub-Saharan Africa (SSA) are also immersed in these dynamics, nuanced by different interests and geopolitical objectives, which vary from one region to the other. The phenomenon of terrorism has also been subject of political manipulations by different actors - Western and regional powers like United States of America (USA) or European countries - in order to promote their own interests and agendas, for example in Middle East. This idea is based on what they did in Afghanistan supposedly fighting against Al-Qaeda and Osama Bin Laden and after that, promoting the emergence of Islamic States (ISIS) with the aim to overthrow the government of Bashar al-Assad and also in the Sahel region after the war in northern Mali. This problematic, the political Islam, the interest of Western powers in Africa and Middle East have been broaden analyzed by Samir Amin (Amin. Samir., Mali. February 4, 20I3).

In this sense, there is no consensus among specialists, about the global responsibility in the emergence and manipulation of this problem. The security mechanisms of USA and its allies of the North Atlantic Treaty Organization (NATO) "engaged" in the "search" and "capture" of the possible suspects of committing terrorist acts, have fostered on one hand the islamophobia and, on the other, the rise of fanaticism in very small sections of the Islamic population. That is why they directly associate terrorism with Islam, and this is a wrong perception. The development of events of an economic, socio-political and military nature, unveiled the intention of the USA governments to manipulate terrorism in their favor.

I Research Center of International Politics, Instituto Superior de Relaciones Internacionales Raúl Roa García. Havana, Cuba. E-mail: yosilglez@yahoo.es 
The study of terrorism requires not only a depth analysis of the historical reasons that led to the formation, development and sustainability of it through the exacerbation and exploitation of fundamentalism, but also the projection of political behavior of this phenomenon in the short and medium term. The objective of this paper is to project the main variables that will determine the trends of terrorism in the case of Africa. Based on a primary diagnosis of the history of this groups and its subsequent development, we pursue to construct the possible scenario for terrorism in Sub-Saharan Africa, taking into account the year 2025 as our horizon: a short-time analysis. There is a set of internal and external economic, sociopolitical, ideological, psychological, religious, cultural and environmental variables, related to national and international interests that could explain the trends that this problem presents in the Sub-Saharan region.

The article is divided in: a methodological and theoretical framework to explain the prospective method used and some ideas about the discussion of terrorism and how to understand it. The second part of the paper focuses on the scenarios, taking into account the development of organizations such as: Al-Qaeda of the Islamic Maghreb (AQIM) and its related groups, Boko Haram (BH) in the area surrounding the Lake Chad, as well as Al-Shabaab (ALS) in southern Somalia and the border with Kenya. We finalized with a generalization of terrorism in Africa - conclusions - and the possible recommendation to solve this problem.

\section{Methodological framework: the scenario-based analysis}

This study was carried out using the prospective method through the methodological tool of the Matrix-based Multiplication Applied to a Classification (MICMAC), created by Michel Godet. This tool allows to determine the direct and indirect influences among the identified variables. It also makes it possible to identify a greater number of relationships between the variables and which of these would be the determinant ones. It's also important to underline that this paper was part of a broaden research that implement a combination of methodologies, not only those coming from the scenarios building process but also from history, international relations and political science.

With this proposal, the definition of the variables, their nomenclature and conceptualization were carried out in a first phase. In a second phase: the quantitative evaluation of the variables was defined through the matrix of direct potential influences. A total of seven variables were determined, which contain other dimensions of each variable. The variable selection does not correspond necessary to a theoretical conceptualization, but to the elements taken 
into account for its analysis: what is to be understood by each of them. In this identification-selection-definition process, a prior diagnosis of the situation of terrorism in sub-Saharan Africa was made. These variables are only a proposal for doing the analysis and any of them could be understood in different ways.

\section{List of variables (nomenclature) and description}

I) Dynamics of the international system (International System): These dynamics are understood as the geopolitical and geo-economic environment that impact on the development of terrorism, as well as the regional economic and social situations that influence the evolution of terrorism.

2) Level of institutionalization (Institutionalization): It is conceived through the functioning of the internal structures, the capacity of spread them to other regions and the organizational stability achieved by terrorist groups and organizations.

3) Level offinancing (Financing): It refers to the self-financing capacity of the group (tax collection, bribes, or ransom payments for kidnappings) and to other income resulting from its connection and/or control of transnational organized crime nets (use of drug trafficking networks, routes of migrants and weapons). It is also referred to the resources coming from political and private actors, as well as for the illegal commercialization of commodities.

4) Recruitment capacity (Recruitment capacity): Level of manipulation of ideological factors, including religion, to attract adherents to its cause, using the Technologies of Information and Communications (media influence) and/or other means to promote fanaticism. This capacity for recruitment is expressed through the support of certain sectors of the population - exchange of information - that identify with their objectives and see their affiliations to them as a means of subsistence. For these reasons they are integrated into the group.

5) Leadership (Leadership): Capacity of influence of their individual leaders and/or incidence of the group/organization at local, regional or international level.

6) Relations between groups/organizations (Relations groups): Dynamics of connection between them or level of autonomy and dependence through the exchange of information, logistical support and ability to train its own members or to train terrorists from other cells. 
7) Violent actions (Violent actions): Availability of armaments, means of combat and military technology for the execution of their terrorist actions and/or the confrontation against regular forces or against civil populations.

During the investigation several methodological difficulties were presented related to the nature of the studied phenomenon, the number of organizations, the geographical variety where they operate and also the possibilities offer by the prospective technique itself. There were several possibilities for addressing the issue: perform the analysis of the variables and the matrix for each terrorist organization, do it at the level of the subregions, or the third variant, related to the general analysis of the phenomenon. Of these three possibilities, the third option was chosen to emphasize the common elements of terrorism in each region and then indicate the general trend in the short term.

In this way, with the results offered by the MICMAC, the analysis of these data was made considering the particularities of each terrorist group/ organization in their specific scenarios. It was decided to apply the method from the general to the particular to see how each of the general tendencies offered by the method fitted the specific case or not. This implied that the results obtained after the application of this foresight tool - in relation to a certain variable - were not always in accordance with the specific evolution that the group/organization will present. This is one of the limits that this tool could have. Spite of that, the results offered by the MICMAC allowed a better validation of the main trends of terrorism in Africa.

\section{Table 1: Matrix of direct influences (MDI)}

\begin{tabular}{|c|c|c|c|c|c|c|c|}
\hline Variables & 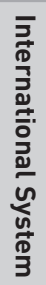 & 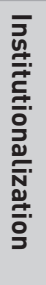 & 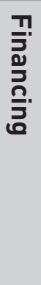 & 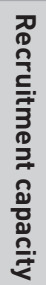 & 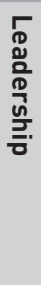 & 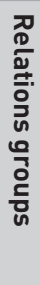 & 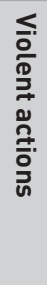 \\
\hline 1. InTERnAtIONAL System & 0 & 2 & 3 & 2 & 2 & 3 & 3 \\
\hline 2. INSTITUTIONALIZATION & 1 & 0 & 3 & 3 & 3 & 2 & 3 \\
\hline 3. FINANCING & 2 & 3 & 0 & 3 & 3 & 3 & 3 \\
\hline 4. Recruitment Capacity & 2 & 2 & 3 & 0 & 3 & 2 & 3 \\
\hline 5. LEADERSHIP & 2 & 3 & 3 & 3 & 0 & 2 & 3 \\
\hline 6. Relations Groups & 3 & 1 & 3 & 3 & 3 & 0 & 2 \\
\hline 7. Violent Actions & 3 & 3 & 3 & 3 & 3 & 2 & 0 \\
\hline
\end{tabular}


Image 1: Potential direct influence/dependence map

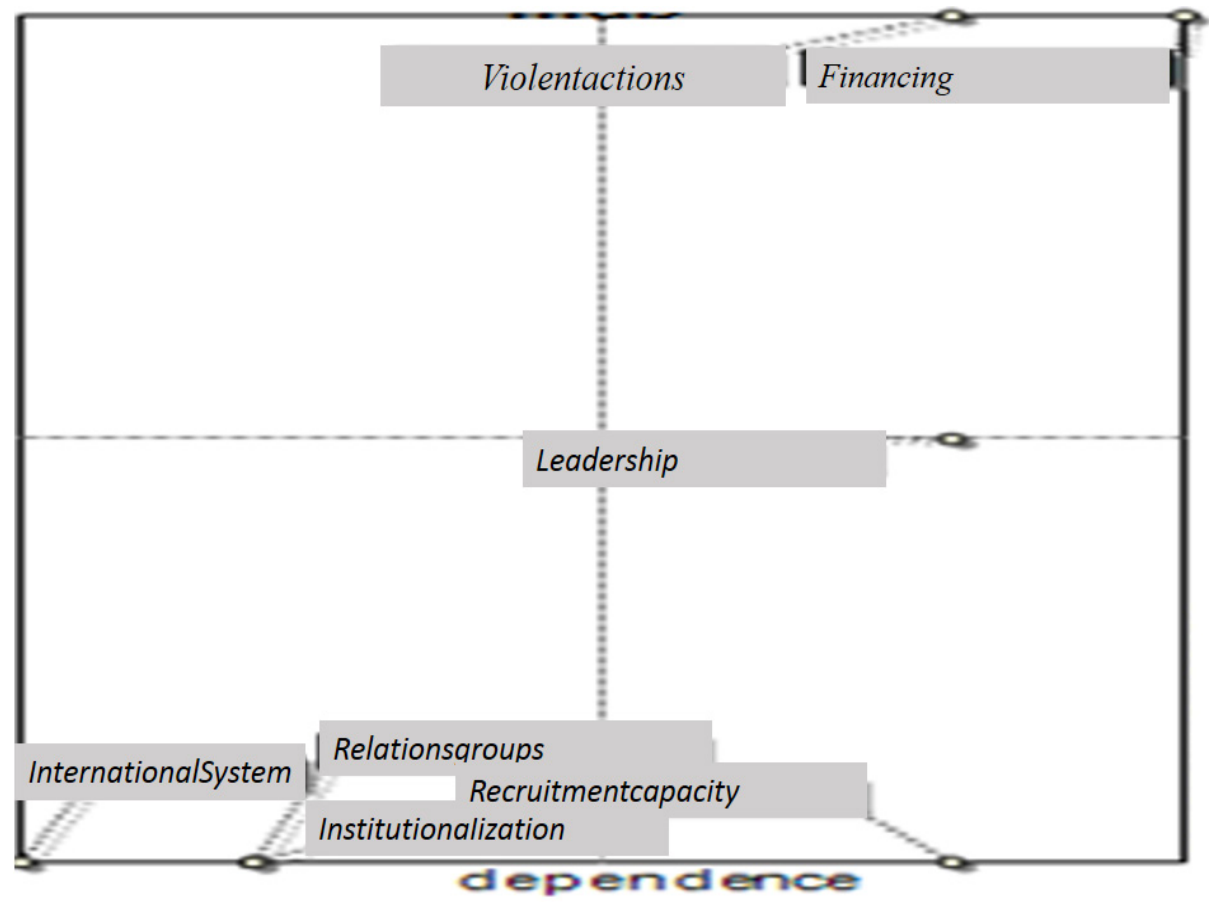

After selecting the variables, the next step is to complete the Matrix of Direct Influence (MDI). It describes the relations of direct influences between the variables defines in the system. Influences range from $\circ$ to 3 , with the possibility to identify potential influences, in this case: o means no influence; I: weak; 2: moderate and 3: strong influence.

These values were adopted after several meetings with a group of experts. For doing this, the scholar have to question him/herself about how does the variable I influence the variable 2 , and so on for the rest of the variables. Of course, the level of influence of one variable over itself is zero, that's why you can see a diagonal line only with zero numbers. Each specialist are supposed to fill up its own table and after that one have to select the number that is more represented. This process does not allow that one opinion prevail over the others.

The MICMAC program showed the following graph (Image I) where the variables are located in a plane of influence/dependence, which allow the analysis to be carried out based on the relationships between the variables and their importance within the object of study. According to this graph the variables of violent actions, financing and leadership are the most influence 
(that's why they are located in top of the graph), meanwhile the rest of the variable are located on bottom, it means that this variable has no influence over the system, and, therefore, the other variables are highly dependents.

Taking these results into account, an analysis of each of the interrelationships of these variables is proposed, according to the trends that the three most active terrorist organizations in the region will present by 2025 : AQIM, BH and ALS. In this work only one of the multiple variants that the MICMAC can offer is shown. It's important to notice that this result can't be literally taken, because each group behave in different ways. This graph is only a general proposal according to the values that the experts adopted and it can be modified depending on the context.

\section{Board 2: Main three African terrorism organizations and the correlation with the variables}

\begin{tabular}{|c|c|c|c|}
\hline $\begin{array}{l}\text { Groups } \\
\text { variables }\end{array}$ & $\begin{array}{l}\text { Al-Qaeda of the Islamic } \\
\text { Maghreb (AQIM) }\end{array}$ & Boko Haram (BH) & Al-Shabaab (ALS) \\
\hline $\begin{array}{l}\text { Dynamics of } \\
\text { the } \\
\text { International } \\
\text { System }\end{array}$ & $\begin{array}{l}\text { Do not had a direct impact } \\
\text { on the rise of AQIM, except } \\
\text { in conjecture contexts, from } \\
\text { which it has benefited, as } \\
\text { those occurred after the } \\
\text { intervention of NATO in Libya } \\
\text { in 2011. The political situa- } \\
\text { tions of the subregion, have } \\
\text { influence a lot on the devel- } \\
\text { opment of the organization. }\end{array}$ & $\begin{array}{l}\text { The dynamics of the } \\
\text { international system do } \\
\text { not have also a direct } \\
\text { influence on the devel- } \\
\text { opment of terrorism. }\end{array}$ & $\begin{array}{l}\text { The subregional } \\
\text { geopolitics of Horn } \\
\text { of Africa has a } \\
\text { remarkable influ- } \\
\text { ence on the evolu- } \\
\text { tion of terrorism, } \\
\text { because the actions } \\
\text { of the governments } \\
\text { of the area. }\end{array}$ \\
\hline $\begin{array}{l}\text { Level of } \\
\text { Institutional- } \\
\text { ization }\end{array}$ & $\begin{array}{l}\text { It has a low level of institu- } \\
\text { tionalization. }\end{array}$ & $\begin{array}{l}\text { It faces of a greater } \\
\text { fragmentation and } \\
\text { des-institutionalization } \\
\text { but this process can't } \\
\text { be associated with its } \\
\text { disappearance. }\end{array}$ & $\begin{array}{l}\text { ALS present seri- } \\
\text { ous difficulties in } \\
\text { the functioning of } \\
\text { its structures. It is } \\
\text { not in position to } \\
\text { externalize these } \\
\text { structures outside } \\
\text { Somali borders. } \\
\text { The group does not } \\
\text { have an organiza- } \\
\text { tional stability. }\end{array}$ \\
\hline
\end{tabular}




\begin{tabular}{|c|c|c|c|}
\hline $\begin{array}{l}\text { Level of } \\
\text { financing }\end{array}$ & $\begin{array}{l}\text { Its comes from the control } \\
\text { of transnational crime net- } \\
\text { works, kidnaps from west- } \\
\text { erns citizens and ransom. }\end{array}$ & $\begin{array}{l}\text { It depends on the con- } \\
\text { trol of international } \\
\text { trafficking networks - } \\
\text { arms, drugs and people } \\
\text { and others resources } \\
\text { coming from political } \\
\text { and private actors. }\end{array}$ & $\begin{array}{l}\text { It self-financing } \\
\text { coming from the } \\
\text { collection of taxes } \\
\text { and bribes and } \\
\text { also receive other } \\
\text { income from the } \\
\text { Somali diaspora } \\
\text { and the control of } \\
\text { other transnational } \\
\text { criminal activities. }\end{array}$ \\
\hline $\begin{array}{l}\text { Recruitment } \\
\text { capacity }\end{array}$ & $\begin{array}{l}\text { Based on economic factors } \\
\text { and not so much on ideo- } \\
\text { logical conviction of its new } \\
\text { members. }\end{array}$ & $\begin{array}{l}\text { Their social support is } \\
\text { considerably reduced } \\
\text { which translates into } \\
\text { the need for this group } \\
\text { to perform forced } \\
\text { recruitments of the civil- } \\
\text { ian population through } \\
\text { kidnapping, compulsory } \\
\text { marriage and the use of } \\
\text { women and children as } \\
\text { "suicide bombers". }\end{array}$ & $\begin{array}{l}\text { It is characterized } \\
\text { by the combination } \\
\text { of voluntary and } \\
\text { compulsory factors. } \\
\text { For many people } \\
\text { ALS is an alterna- } \\
\text { tive for their eco- } \\
\text { nomic subsistence: } \\
\text { receiving a salary, } \\
\text { social status and } \\
\text { even a wife. }\end{array}$ \\
\hline Leadership & $\begin{array}{l}\text { It's exercised fundamentally } \\
\text { by its component of Arab } \\
\text { origin, although there is an } \\
\text { increase in the emergence of } \\
\text { Black-African origin leaders, } \\
\text { especially in the smaller } \\
\text { cells. }\end{array}$ & $\begin{array}{l}\text { The physical elimination } \\
\text { of the terrorist leaders } \\
\text { does not mean a weak- } \\
\text { ening of the group since } \\
\text { the tendency indicates } \\
\text { that they are replaced } \\
\text { immediately. }\end{array}$ & $\begin{array}{l}\text { The capacity of } \\
\text { influence of its } \\
\text { new leaders is very } \\
\text { weak, as well as } \\
\text { the incidence of the } \\
\text { group at local and } \\
\text { subregional level. }\end{array}$ \\
\hline $\begin{array}{l}\text { Relations } \\
\text { between } \\
\text { groups/ } \\
\text { organizations }\end{array}$ & $\begin{array}{l}\text { - Al-Qaeda } \\
\text { - Islamic States in the } \\
\text { Greater Sahara (ISGS) } \\
\text { - Ansaroul Islam } \\
\text { - Movement for the Unity and } \\
\text { Jihad in West Africa (MUJAO) } \\
\text { - Macina Liberation Front } \\
\text { (MLF) } \\
\text { - Ansar al Dine } \\
\text { - Al-Mourabitum } \\
\text { - Support Front to Islam and } \\
\text { Muslims (Jama'at Nusrat al } \\
\text { Islam Wal Muslimin, JNIM) } \\
\text { - Boko Haram }\end{array}$ & $\begin{array}{l}\text { - Islamic States (ISIS) } \\
\text { - Islamic States in West } \\
\text { Africa (ISWA) } \\
\text { - Ansaru - Vanguards } \\
\text { for the Protection of } \\
\text { Muslims in Black Africa } \\
\text { - when it was separated } \\
\text { from Boko Haram in } \\
2012 \text {. }\end{array}$ & $\begin{array}{l}\text { There is a reduction } \\
\text { in the dependence } \\
\text { of ALS on Al Qaeda. } \\
\text { Relations with } \\
\text { Al Qaeda of the } \\
\text { Arabian Peninsula } \\
\text { (AQAP) are stag- } \\
\text { nant. } \\
\text { The Islamic States } \\
\text { (ISIS) has created } \\
\text { fissures within the } \\
\text { group but ALS exe- } \\
\text { cute the accused of } \\
\text { being pro-Islamic } \\
\text { State. }\end{array}$ \\
\hline
\end{tabular}




\begin{tabular}{|l|l|l|l|}
\hline & $\begin{array}{l}\text { They operate in the } \\
\text { Trans-Saharan region: Mali, } \\
\text { Niger, and Burkina Faso. } \\
\text { There has been an increase } \\
\text { of the actions of some of } \\
\text { its cells in the bordering } \\
\text { areas of Mali and Burkina } \\
\begin{array}{l}\text { Faso. They use car bombs, } \\
\text { improvised explosive devices, } \\
\text { ambushes, placement of } \\
\text { mines and attacks against } \\
\text { checkpoints on roads. }\end{array}\end{array}$ & $\begin{array}{l}\text { Take places in the area } \\
\text { surrounding the Lake } \\
\text { Chad: northern Nige- } \\
\text { ria - Borno state - and } \\
\text { bordering countries. } \\
\text { There is a reduction of } \\
\text { its military operations } \\
\text { theater and the loss } \\
\text { of effective control of } \\
\text { territories and towns. }\end{array}$ & $\begin{array}{l}\text { It acts in southern } \\
\text { bomalia and the } \\
\text { against AMISOM } \\
\text { and Kenyan forces } \\
\text { in the Gedo and } \\
\text { Upper Jubba } \\
\text { regions. They use } \\
\text { car bombs, and } \\
\text { improvised explo- } \\
\text { sive devices. }\end{array}$ \\
\hline
\end{tabular}

\section{Theoretical framework: understanding terrorism}

Through a powerful and well-designed communicational gear, the so-called war on terrorism is presented, by Western countries, as a method of "protection and salvation" against their actions. This propaganda omits the true causes behind the rise of such phenomena as poverty, insecurity and social inequalities caused by the application of structural adjustment programs in African. This phenomenon began to affect African countries in the last two decades. Regions like the Horn of Africa and the Sahel, which includes territories of West and Central Africa, have become areas of attention and central axes of the so-called fight against terrorism on the continent, due to the maintenance of the actions of extremist groups such as ALS (since 2006), AQMI (since 2007) and the Movement for the Uniqueness of Jihad in West Africa (MUYAO since 20I2) in Western Sahel and BK in northern Nigeria (since 2009).

The actions of these organizations have been concentrated against the governmental institutions of the countries of the area, against the national populations - civilian victims -, and in the same way, against the foreign interests, mainly European: sabotage activities to the properties of transnational companies and kidnappings of European tourists. Due to the strong manipulation to which they are subjected, every political-military movement that arises in the region is almost automatically classified as a terrorist if they do not respond to the interests of extra-regional or regional powers.

This problem has led to the adoption of institutional initiatives within the framework of the UN, where the Counter-Terrorism Committee was created, based on the provisions of Security Council resolutions I373 (200I) and $6_{24}(2005)$. Its objective was to strengthen the capacities of member states to combat terrorist activities within their borders and in all regions. 
The Counter-Terrorism Committee and its Executive Directorate had the responsibility of monitoring the implementation of Security Council resolutions. Subsequently, the UN Secretary General established in 2005, the Special Team for the Fight against Terrorism and on September 8, 2006, the General Assembly approved the Global Strategy against Terrorism. It was the first time that the states agreed on a global framework to face this scourge.

Under the auspices of the United Nations and other intergovernmental organizations, I 6 universal legal instruments have been developed and approved, namely in conventions, 4 protocols and an amendment. Most of these instruments are in force and constitute the legal framework for the adoption of multilateral counter-terrorism measures, as well as the criminalization of specific acts of terrorism, including the diversion of airplanes, the taking of hostages, the attacks committed. With bombs and their financing ${ }^{2}$.

In this context, Western powers began to categorize certain countries as "sponsors" of terrorism to justify international pressure actions and intervene in the internal affairs of those governments that did not have the capacity to deal with these groups and thus achieve certain objectives, such as changes in government, for example, in Iraq, Afghanistan and Libya. Similarly, they developed lists of organizations classified by them as terrorists, which rise a strong debate between academics and politicians about how to define what terrorism is.

For Cuban professor Elsie Plain Rad Cliff (20II), terrorism is the application of indiscriminate violence that can be extended to the entire population and in most cases takes civilians as the target of their attacks. Their actions are unpredictable due to the surprise with which they always act, which contributes to: instilling terror; produces unnecessary suffering by hitting the most vulnerable areas of society; employs hostages and human shields to achieve what they propose. Among the most commonly used methods are the use of indiscriminate physical violence against: civilians, through torture, kidnapping, extrajudicial execution or disappearance. In the tactical order they can adopt a scheme based on the realization of attacks with explosives or other incendiary means for the destruction of private and public goods (Cliff 20II, IOI-II5). A terrorist is an individual who acts against civilians using illegal methods to achieve a political goal.

2 These instruments are complemented by the following General Assembly resolutions: A / RES / 49/60, A / RES / 5I/2IO and A / RES / 60/288; and the Security Council: S / RES / I267 (I999), S / RES / I373 (200I), S / RES / I540 (2004), S / RES / I566 (2004) and S / RES / I624 (2005). See: United Nations actions against terrorism. Available in: http:// www.un.org/spanish/terrorism/strategy-implementation.shtml 
All this has evidently complicated with the ig conventions against terrorism and resolutions adopted by the Security Council, with the exception of resolutions I269 (I999) and I566 (2004) where it is indicated that, whatever their motivation, no terrorist act is justifiable. From this situation derives the complexity of establishing a definition on terrorism, due to the lack of consensus on the part of the international community and depending on who is assessing it. This problem has also served to increase the level of conflictive in international relations and at the same time, the militarization of them, due to the increase in military budgets to "confront" the actions of groups hostile to the interests of developed capitalist countries and its regional allies.

For its part, the African Union (AU) and its subregional organizations did not lag behind, rather, they were pioneers in the implementation of legal mechanisms to combat terrorism. One year after the attacks on the US embassies in Nairobi (Kenya) and Dar es Salaam (Tanzania) in East Africa, in I998, the Organization for African Unity (OAU) had adopted, at its 35th Summit, held in Algiers (Algeria) in July I999, the Convention on Prevention and the Fight against Terrorism. This document was a milestone, as it was the first legislative instrument made for its confrontation.

This I999 convention was followed by the OAU Protocol for the prevention and fight against terrorism (Protocol of the OAU Convention on the prevention and combating terrorism 2004, 2). The next steps that evidenced the African commitment in the fight against terrorism were expressed at the Dakar Summit (Senegal) in October 200I, where the Dakar Declaration against terrorism was adopted. Then the Action Plan for the Prevention and Combat of Terrorism was approved, at a high-level Intergovernmental Summit developed in Algeria in September 2002. In 2002, the newly created AU had adopted the Action Plan on Prevention and Fight against Terrorism, and subsequently with the implementation of the Peace and Security Council, as the governing body for conflict issues, the institutional apparatus was strengthened in the fight against terrorism. An important step was the creation of the African Center for the Study and Research on Terrorism (ACSRT) whose headquarters are in Algiers, Algeria.

For the purpose of this paper, we are going to adopt the concept of terrorism approved by the OAU in I999 in Algiers, which constitute the first instrument in understanding terrorism in the region. This principle was also embraced by the AU after its creation in 2002. The main contribution of this concept was a broad definition of terrorism without the qualification of Islamic and the differentiation between terrorist acts and the actions developed 
by groups in their struggle for self-determination. According to the OAU Convention on the Prevention and Combating of Terrorism, a terrorist act is

any act which is a violation of the criminal laws of a State Party and which may endanger the life, physical integrity or freedom of, or cause serious injury or death to any person, any number or group of persons or causes or may cause damage to public or private property, natural resources, environmental or cultural heritage and is calculated or intended to: intimidate, put in fear, force, coerce or induce any government, body, institution, the general public or any segment thereof, to do or abstain from doing any act, or to adopt or abandon a particular standpoint, or to act according to certain principles; or disrupt any public service, the delivery of any essential Service to the public or to create a public emergency; or create general insurrection in a state (OAU Convention on the Prevention and Combating of Terrorism I999, 2-3).

An exact definition that characterizes the actions of the groups that operate in Africa is that offered by the Spanish professor Fernando Reinares (2005) in his concept of transnational terrorism. Reinares states that transnational terrorism

is one that in one way or another crosses state borders, basically because those who execute it maintain organizational structures or develop violent activities in more than one country, usually including territories over which they have no jurisdiction the authorities. (...) This means that acts of violence involve more than one country and often individuals of two or more nationalities, both in terms of terrorists and their victims (Reinares 2005, 48).

\section{Terrorism in Africa: future trends}

Terrorism in sub-Saharan Africa presents different characteristics from those that occur in the Middle East region. In this sense, the most extreme variants, which have later become terrorists, have been perceived as foreign elements, exogenous to African realities, and thus they have had an almost generalized rejection from the population and have not been able to spread to other regions, except by the way of force. For these reasons is not possible that certain cells in Democratic Republic of Congo and in northern Mozambique could intensify its military actions. It should be noted that a distinctive element between the radical groups that act in the Middle East 
from those that operate in sub-Saharan Africa is the fact that in their origins, the second one, did not used terrorist methods.

This means that groups like BH and ALS started out, in its early beginnings, as groups that made political and socio-economic demands to the local governments and later became radicalized. In the case of AQIM, its Saharan branches were controlled by Algerian Arabs and Black-Africans were excluded from the leadership roles although years after the situation start changing (Filiu, Jean Pierrre 20I2; Furuhashi, Yoshie 20I2). This is the way this organization was presented as a non-genuine organization of the

sub-Saharan region and this caused start contradictions between different factions or katibas. Among other differences can be mentioned the fact that they have not been financed by Western powers or regional governments as they have done in Middle East. Its prominent interethnic character has been a factor that limited the greater propagation of its networks towards other areas.

\section{Al-Qaeda of the Islamic Maghreb and its transaharian action}

The permanence of terrorist activism in 2025 still remains a particularity of the Sahel-Saharan zone. Although the stabilization attempts of governments such as Algeria, Mali and Niger, can gain recognition and effectiveness in the area, the relative autonomy of this organization suggests that insecurity and instability will continue to be a condition desired by groups that maintain their control over the main vulnerable zones.

Although it is not possible to deny the traditional impact of the dynamics of the international system, even in sub-Saharan Africa, these have not had a direct impact on the rise of AQIM, except in conjuncture contexts, from which it has benefited, as those occurred after the intervention of NATO in Libya in 20II (Amin. Samir., Mali. February 4, 20I3). In this sense, the political situations of the subregion, have influence a lot on the development of the organization, because the greater or lesser coordination of the governments of the area that will enable their weakening or strengthening. If policies are maintained by the Economic Community of West Africans States (ECOWAS) the possible scenario will led to a reduction of this group. The tendency points to a greater articulation of the antiterrorist policies of the governments of the area to confront this transnational group. On the other hand, the relations between the different terrorist groups that operate under the AQIM's umbrella will remain diffuse. However, the great fragmentation experienced by the organization in recent years corresponds more to a strategy adopted 
by them than to a greater weakening, since the constant recomposition of its internal forces hinders its effective eradication.

Therefore, the organization will continue to lead a broad and increasingly volatile group of cells and terrorist groups operating in the wider Trans-Saharan region. In turn, it will maintain the line established by Al-Qaeda, while the splits of leaders linked to the remnants of the Islamic State (ISIS) do not have a positive development in the area. Only in this sense can be understood that the level of institutionalization and leadership of the organization work as very influential variables in the development of terrorism in the Sahel.

The leadership within this group is dispersed, which responds to the levels of fragmentation of the organization. This continues to be exercised fundamentally by its component of Arab origin, although there is an increase in the emergence of Black-African origin leaders, especially in the smaller cells. This fragmentation can't be confused with a low level of institutionalization, since each one of the cells will continue to respond to the central command of AQIM that is still located in the Algerian mountains of the Kabylia region (Oumar, Jemal and Bakari Gueye 2013).

Likewise, the recruitment capacity of the organization is produced as a highly dependent dimension with little influence. The units that make up AQIM seem to subordinate the recruitment to the needs of expanding its membership as a result of the military offensives launched by the governments of the area that have undoubtedly affected their activism. In the recruitment of this group will continue to have a fundamental weight economic factors and not so much the ideological conviction of its new members. It means that Islam, contrary to popular belief, will not be the main factor for the recruitment. The socio-economic crisis in the regions where it operates remains the main reason why potential new recruits are linked to AQIM networks, as a form of "work" and obtain "income" because of its link with other transnational crime networks.

\section{Terrorism around Lake Chad: Boko Haram}

The security landscape in the Sahel zone remains very unstable in 2025 due to the maintenance of the actions of the terrorist groups - most of them reconfigured - so this phenomenon will persist within the agendas of the governments direct or indirectly affected by their actions. One of the nerve centers of this terrorism will continue to be located around the area of 
Lake Chad with an epicenter located in northern Nigeria and with specific ramifications towards the bordering countries.

In the case of the Sahel region, the dynamics of the international system do not have also a direct influence on the development of terrorism, because its solution is not within the priorities of the Western powers, despite the rhetoric that is used by France and the United States regarding the "fight against terrorism".

Despite the adverse socio-economic situation in these regions, this variable will not have a direct influence on the development of this issue due to the rejection they generate in local populations as a result of the negative consequences that their actions have generated in recent years. This economic context also does not allow them to extend to other regions to "legitimize" their "antisystemic" political discourse. Their social support is considerably reduced and they can't "satisfy" the demands of the populations in economic terms. The discourse of the leaders of $\mathrm{BH}$ fails to add new followers. They can do that only by the use of coercion.

In this sense, the MICMAC program showed that the recruitment capacity is a strongly dependent variable, which translates into the need for this group to perform forced recruitments of the civilian population through kidnapping 3 , compulsory marriage and the use of women ${ }^{4}$ and children ${ }^{5}$ as "suicide bombers". Their inability to recruit is also related to the loss of social support as it was mentioned before. Nevertheless, the group will maintain this

3 According to Human Rights Watch, Boko Haram has kidnapped 2,000 girls and women since 2009, who have been subjected to rape, forced labor and marriage. However, these figures are only approximate because one can't determine how many have been kidnapped. According to the Foundation for the Defense of Democracies (FDD), since 20I4 there have been at least I23 "suicidal" women linked to BH, most of them forced. See: The women of Boko Haram: Driven to extremism. Available in: http://www.dw.com/en/the-women-of-boko-haram-driven-to-extremism/o4

4 A United Nations Children's Fund (UNICEF) report indicates that the number of children who are used by Boko Haram as suicide bombers have increased between 2014 and 20I5. As of February 2016 , one of five bomb attacks have been carried out by a child, for I9\%, while I $8 \%$ has been taken performed by women. The report also gives an account of the problems related to the reception of women who have been raped, abducted or forced to marry a member of the group. These women are rejected in the communities when they try to rejoin their daily activities (Duvillier 20I6, 2-4).

5 According to the UNICEF report, BH employs more and more children as suicide bombers. In the first quarter of 2017 the figure has tripled compared to the same period of the previous year, to reach 27, according to Marie-Pierre Poirier, UNICEF regional director for West and Central Africa. During the past three years, II7 children were employed to carry out bomb attacks in the Lake Chad basin. Around $80 \%$ of the attacks were perpetrated by girls (Cubadebate 20I7, I). 
tactic of forced recruitment, which will have an indirect impact on the future evolution of terrorism. Mercenarism, fueled by other actors, as another way to enter their terrorist cells, is not representative in the case of $\mathrm{BH}$, nor will the use of Information and Communications Technologies (ICT) to foment religious fanaticism or strengthen the "support" of other sectors of the population. The broad social bases formed around this group is further dismantled and do not have the same characteristics as it enjoyed in the initial years of its creation.

The MICMAC offered as result that the relations between the groups and the level of institutionalization are autonomous variables that have an indirect influence on the development of terrorism, especially the case of institutionalization. This is explained by the fact that, in most cases, if the group are most fragmented and supposedly "disarticulated", it will be more difficult to be able to implement accurate policies for their final eradication. This fragmentation within the group - of which $\mathrm{BH}$ has also appropriated - responds more to a strategy to operate with a greater capacity than to sign of weakening.

The links between the organizations (Boko Haram-ISIS, Boko HaramAQIM) in terms of information exchanges, logistical support and ability to train terrorists from their cells have not been effective and therefore were not a guarantee for the success of their actions. This fact reaffirms the tendency that, in the face of a greater fragmentation and des-institutionalization of the group, these links will be increasingly smaller and will be more in the level of discursive rhetoric. The different cells that make up BH reach a greater level of autonomy to the extent that the group tends to its disintegration ${ }^{6}$, but this process can't be associated with its disappearance.

The dispersion of the terrorist cells and the little social link of the "insurgency" with its leaders hinders the control over the group. According to the Nigerian professor Mohammed Kyari, of the state of Adamawa, BH is a group of cells operating under a single banner and that the fractures within the group correspond to the way they operate (Matfess 20I6, I). This trend will probably continue. Therefore, the "factionalization" of the group has a negative impact on the possibility of completely eradicating them. This is due to the fact that the emergence of rival factions also causes confrontations between them and between these and the regular forces. Apart from the challenge of dispersion, factional fighting is an additional problem, especially if

6 Boko Haram had called itself Islamic State's West Africa Province (ISWAP) in 20I5, as a proof of its links with the Islamic State. At the beginning of August 20I6, the Islamic State had nominated Abu Musab al-Barnawi as the new "wali" of the group, "replacing" Abubakar Shekau. This provoked a strong polemic inside the group in the matter of leadership and the emergence of two antagonistic factions. 
an attempt is made to produce a negotiation process. Hilary Matfess (2016), American researcher on issues of governance and security in sub-Saharan Africa poses three scenarios related to the process of division within Boko Haram:

I) Development of violence between factions (Shekau vs Barnawi). Contrary to what is thought, these contradictions will not mean the end of the "insurgency" but will be more deadly clashes for the civilian population.

2) Greater division before its complete elimination: This scenario is held in the fate of Ansaru - Vanguards for the Protection of Muslims in Black Africa - when it was separated from Boko Haram in 20I2. In April 20I6, the Nigerian government announced the capture of Khalid al-Barnawi (Watkinson. W. 2016, I), after several years without major terrorist operations, so it was assumed the end of their activities.

3) Coexistence and duality in the terrorist insurgency: in this scenario the faction linked to the Islamic State consolidates as a group and develops its capacities to carry out military and terrorist actions (Matfess 20I6, I).

In all three scenarios, the idea of fragmentation and reconfiguration of BH itself, as well as the cells or factions linked to the group is present. None of these three scenarios suggests the end of terrorist actions around Lake Chad. Therefore, it will continue to be a security problem for the area. The level of institutionalization - understood as the correct functioning of internal structures and organizational stability - is a variable that has a strong relationship with the financing of the group, because it allows the creation of new structures and the strengthening of existing ones. Although its leaders manage to reverse this process of group regression, in organizational matters, this variable will not have a strong influence on the evolution of terrorism, because institutionalization, per se, is not a guarantee of success. Similarly, $\mathrm{BH}$ does not have the capacity to export its organizational structures, that is, to expand its network to other regions beyond its traditional areas of operation.

The tendency in terms of financing terrorism in the Sahel zone points to the continuity of its dependence on the control of international trafficking networks - arms, drugs and people. In the case of $\mathrm{BH}$, its resources have been reduced in order to maintain its military and logistical capabilities, but 
this does not mean that they do not yet have the capacity to "self-manage" . The resources coming from political and private actors - related to their tactics - do not reach the figures shown in the initial years of the group. This situation must also have repercussions in the decrease of their recruitment capacities or in the increase in desertions, which have already taken place. They have also been promoted by the authorities ${ }^{8}$.

Leadership, understood as the ability from its leaders to influence, is another of the driving variables and depends on the charisma of the people who are in charge of the cells that make up the group. If this component is maintained, BH leaders will continue to have a strong influence on the development of the group, despite the internal interest struggles that point to personal positions. Therefore, leadership is exercised at different levels. For example, at the local level, it is very small, while at the regional and international level it is practically non-existent, even with the "disclosure" of the videos showing their actions and the postulates of their political program. At the same time, there are still strong contradictions between the leaders of the different $\mathrm{BH}$ factions. The physical elimination of the terrorist leaders does not mean a weakening of the group since the tendency indicates that they are replaced immediately.

Violent actions have a strong dependence on the military capabilities of the group and have a considerable influence on their positioning - control of villages and areas - through military actions. With respect to Boko Haram, the reduction of its military operations theater and the loss of effective control of territories and towns will continue occurring. The group will maintain its tendency to retreat and dispersion. In the near future they will lose capacity for confrontation against the regular forces from Nigeria ${ }^{9}$ and other local

\footnotetext{
7 According to a report presented to the United Nations Security Council, the two main BH factions present serious financial difficulties and are not in a position to "pay" their fighters their monthly "salaries". Most of the recent attacks are motivated by the need to purchase supplies, including food. The report concludes that the group as a whole is facing a severe financial crisis. See: Gaffey. C. (20I7). Boko Haram Factions 'Cannot Pay Fighters' Salaries: U.N. 8 The Nigerian Army launched the Operation Safe Corridor with the aim of allowing repentant $\mathrm{BH}$ militants to enter the rehabilitation camps as part of a program to reintegrate them into society. See: Gaffey C. (2016). Boko Haram: 2,000 Captives Freed by Regional Force as Nigeria Launches Rehabilitation Program.

9 The Nigerian armed forces have increased their presence in the Sambisa Forest area in the state of Borno and have dominated the area since December 2016.
} 
armies coming from the neighboring countries such as Niger ${ }^{\mathrm{IO}}$ or Cameroon. They also will lose its ability to carry out large-scale operations in the areas recovered by the national armed forces.

This situation has led them to strengthen attacks against easier targets - like civilian population - through the use of suicide attacks, avoiding direct confrontations against regular forces. Therefore, it can be argued that the military offensives of local governments have reduced their capacity to carry out conventional armed actions against the security forces, the transnationalization of their actions is increasingly minor and sporadic, an example of their retreat in the military order. Despite this and the inevitable process of internal fragmentation, they maintain their military power.

\section{The Horn of Africa and the terrorism of Al-Shabaab}

The region of the Horn of Africa by 2025 continues under the threat of terrorist actions by the Somali organization Al-Shabaab (ALS). The most affected countries will be Somalia, where the bulk of the organization is concentrated, and Kenya, one of its main objectives. The situation in Ethiopia, Djibouti and Eritrea is substantially different, but in the case of Ethiopia, although they have not carried out attacks on their territory, it remains a challenge to their national security. This situation explains that the geopolitical environment of the subregion will continue to be nuanced by the issue of the fight against terrorism and the instability that this causes.

Similarly, the subregional geopolitics will have a remarkable influence on the evolution of terrorism, because the actions of the governments of the area contribute by one hand to their eradication, but on the other, they legitimize the discourse of combating the external interferences in the area, as the group affirm. One of the points within the political program of ALS is the "struggle" against foreign troops, among which are those from Ethiopia and Kenya as part of AMISOM (African Union Mission for Somalia). Therefore, contrary to the result offered by the MICMAC regarding the variable related to the international situation, the subregional political dynamics here do have a paramount importance in the evolution of terrorism.

Io Military successes by national armies continue to occur. One of the examples was the defeat of $\mathrm{BH}$ in April $20 \mathrm{I7}$ by the Niger Army in the southern region of Diffa on the border with Nigeria, where as a result of the Army's counter-offensive, $57 \mathrm{BH}$ members were eliminated and a large military park was seized. The Minister of Defense congratulated the Security Forces. See: Sridharan. V (20I7). Niger forces kill dozens of Boko Haram Islamists in counteroffensive. 
An element that has been characteristic of this type of groups has been the fact of "swearing" allegiance to larger organizations such as Al-Qaeda and ISIS. In this sense, ALS relations with central Al-Qaeda by 2025 are not strong enough to "boost" the organization and increase its subregional projection. Al-Qaeda itself is going through a period of institutional crisis and loss of leadership within terrorist organizations, so this will have a negative impact on its ability to unite other groups such as ALS. There is a reduction in the dependence of ALS on Al-Qaeda, as well as the ability to carry out information exchanges, logistically support and train members of their cells. Relations with Al-Qaeda of the Arabian Peninsula (AQAP) are stagnant, especially in terms of mutual support in training its members, as it existed before.

On the other hand, relations with other groups or organizations are equally weak, precisely because of the process of decline that is taking place within terrorism in the region. ISIS does not manage to incorporate ALS to its axis of influence but it has created fissures within the group ${ }^{\text {II }}$. In this sense, ALS is forced to achieve a greater degree of autonomy in terms of its "strategy" of struggle as the only way to "strengthen" its political program and do not show an image of exclusion or marginalization within the networks of international terrorism.

There is an evidence that there may be more supporters of the ISIS in southern Somalia, but the control exercised by ALS has not allowed them to be articulated. This indicates the inability of ALS to neutralize ISIS supporters within the organization. To this end, the "secret services" of ALS Amniyat - have been making "arrests" of members of the group on suspicion of having an inclination towards ISIS. The Amniyat continues with its ability to perform intelligence work, through a wide network of supporters, informants and spies that are scattered throughout the country. They also have the possibility of infiltrating government structures, as well as the Somalia National Army (SNA) (Danish Immigration Service 20I7, Io).

II On October 25, 20I5, Abdiqadir Mumin, who was one of the "spiritual leaders" of ALS, left the group to pay homage to the ISIS. This new franchise led by Mumin has its operations center in the Galgala Mountains in the Puntland region in northeastern Somalia, outside of the traditional zone of influence of ALS. In April 2016 they became official as Jahba East Africa and in October of the same year they carried out their first major attack against Qandala, a port city in Puntland. See: Reid. G. (20I7). Militants Rising: Islamic State's East African Ambitions. 
The contradictions have led to Al-Shabaab to execute the accused of being pro-Islamic State ${ }^{12}$. There is no clarity regarding the possibilities that this faction will continue to evolve, nor the number of members that may be available. As is often the case, the links with ISIS in the Middle East are not direct, but are part of the rhetoric to attract international attention. This weakness in its international "projection" is also a reflection of the problems within the group. ALS continues to present serious difficulties in the functioning of its management structures due to the struggles among its leaders regarding strategies, methods and objectives to be followed by the group. Nor is it in a position to externalize these structures outside Somali borders, precisely because of the policies adopted by the main regional actors in their fight against terrorism: Ethiopia and Kenya. In the Kenyan border and due to the strong presence of Somali refugees, they manage to transplant some of their cells and support networks, but they are not significant either. As a consequence, the group does not have an organizational stability, which is evident in the continuous transformation of its commands and leaders, as a result also of the elimination of them, by the selective drone attacks carried out by the United States and by the actions of AMISOM ${ }^{13}$.

One of the problems ALS continues to face is that of desertions. The main ones are taking place among the younger militants as part of a growing discontent in leadership, especially from those non-Somali militants, the so-called foreign fighters. The group needs these members to give greater legitimacy to their "jihadist" struggle (Kriel. R. and Duggan. B. 20I7, I). Those who leave the group also do so for reasons of amnesty policies which have been implementing by the Somali government is implementing as another way to dismantle them ${ }^{\mathrm{I} 4}$. This variant will not have a generalizing effect due to the retaliation of ALS against all those who resign from the group ${ }^{15}$. The institutionalization process experienced by the country after $20 \mathrm{I} 2$ and $20 \mathrm{I} 6$

I2 Sheikh Hussein Abdi Gedi was a veteran ALS commander and "governor" of the Lower Jubba region who was killed after trying to recruit ALS militants and form a pro-IS militia in the Kismayo area. See: Platt. S. (20I7). Al-Shabaab update: February 2017.

I3 According to AMISOM reports, several ALS leaders have been eliminated. See: Reuters. (20I6). AU mission says several al-Shabaab commanders killed in Somalia.

I4 One of the ALS leaders, Hussein Mukhtar surrendered to the Somali National Army in Baidoa in March 20I7. See: Agutu. N. (20I7). Al Shabaab top leader Hussein Mukhtar surrenders to Somali army.

I5 The defectors are one of the main targets of the group because they can have information that affects them. ALS uses all its informant networks to locate and eliminate those who leave the group, even if they relocate to areas controlled by AMISOM and the government. 
elections have also facilitated the reduction of $\mathrm{ALS}^{\mathrm{I}}$. This also will contribute with the consolidation of the local and regional authorities.

The relationships of alliances are very diffuse due to the complexity of the clan and sub-clan framework. As part of the support networks of ALS, there are also relations with the heads of minority clans and their respective militias, mainly in the southern part of the country. These links allow the advancement of the group, access to supplies and recruitment. At the same time, there are militias that oppose the military presence of ALS; therefore, this element must be seen region by region and is modified with the passage of time. The foregoing indicates that the contradictions between these actors will not be eliminated in the short term and these also act as an element to stop further progress of ALS in certain regions, although their military strength remains, being superior to these militias that have a local character and smaller "national" scope.

The MICMAC indicated that leadership is a driving variable due to its levels of influence. In the specific case of the situation of ALS, it would be necessary to say that the capacity of influence of its new leaders is very weak, as well as the incidence of the group at local and subregional level. This translates into their inability to serve as a "reference" to other smaller organizations. At the international level they have no impact, since their military potential does not allow them to carry out cross-border actions beyond the subregion in which they traditionally operate. In this way, the reduction of leadership has a positive effect on the decline of the group in the short and medium term, but even so, it receives the support of important sectors of the population.

Their social base is not reduced and a lot of people see ALS as an alternative for their subsistence. A large part of the population in rural areas under their control, "prefer" the "security" that is offered by ALS, since they manage to "organize" social structures according to their conceptions and not the legal vacuum offered by regional and "federal" authorities. The levels of coercion that the group exercises in the areas they control will also continue to play a fundamental role. This situation is related to the recruitment process, which is characterized by the combination of voluntary and compulsory factors. Reducing their leadership does not necessarily imply a decrease in their recruitment capabilities. The adverse internal socioeconomic context

I6 The last presidential elections took place between November 2016 and February 20I7, when the 328-member Parliament elected former Prime Minister Mohamed Abdullahi Farmajo as President of Somalia. Farmajo won the presidency I84 votes against 97 in favor of Hassan Sheikh Mohamud, in the presidency since 20I2. See: Nor. O., Sevenzo, F., \& Masters, J. (20I7). Mohamed Abdullahi Farmajo elected Somalia's president. 
in Somalia $-64 \%$ of young people between I4 and 29 are unemployed -, also exacerbated by the same actions of ALS, favors the attraction of new adherents to their cause ${ }^{\mathrm{I} 7}$.

The manipulation of ideological factors, including religion, through the use of a well-structured network of propaganda and dissemination: radio, social networks, internet and Medias ${ }^{18}$, are effective in achieving the incorporation of new combatants. One of the incentives for recruitment remains the possibility of receiving a salary, social status and even a wife in the territories they control. Another way of recruitment also occurs through mosques and inter-clan rivalries. ALS uses these rivalries to integrate members of minority clans with the promise of greater status (South and Central Somalia Security Situation, al-Shabaab Presence, and Target Groups. 20I7, 20).

Forced recruitment will remain characteristic of areas that are completely under their control. If a person refuses to be recruited, he must pay some compensation. Denial often has negative consequences. The phenomenon of the use of children as combatants is also occurring in ALS. In 20I4, 437 child soldiers were reported and 555 in 2015 , and in 2016 there were about 1.560 reported cases (South and Central Somalia Security Situation, al-Shabaab Presence, and Target Groups. 20I7, 2I). The average age for recruitments is between I4 and 25 years. ALS also continues to recruit women for logistics work, serve as wives, attract other women, collect information and use them as suicide bombers because of their easiness to move from one place to another (South and Central Somalia Security Situation, al-Shabaab Presence, and Target Groups. 20I7, 22).

Financing terrorism remains the most influential variable within the system for the continuity of groups and their programs. In this sense, ALS maintains the capacity for self-financing through the collection of taxes and bribes. In the same way, it continues to receive other income because of "donations" from its Somali supporters in the diaspora and those who have become delinquent due to their transnational criminal activities (use of drug trafficking and weapons networks). The group's sources of self-financing are given by the tax system and the work of the Sharia Courts. The system of collection of taxes is part of the administrative order in the regions that control and is considered as more "fair" than the government. At the same time, they manage a judicial system based on Sharia and due to the malfunc-

I7 $50 \%$ of ALS dropouts have declared joining the group for economic reasons. See: South and Central Somalia Security Situation, al-Shabaab Presence, and Target Groups. 2017, 20.

I8 Shahada News Agency is the name given to the news agency belonging to ALS through which they transmit their statements to the media. 
tion of the legal system in the country, many people turn to the Courts of ALS when they are not satisfied with a ruling by a governmental and secular court (South and Central Somalia Security Situation, al-Shabaab Presence, and Target Groups. 20I7, II).

Despite the organizational problems, the group still has weapons, means of combat and military technology for the execution of its terrorist actions and the confrontation against the regular force, the AMISOM troops or the local security militias and the SNA. Their military actions will continue to be focused on the attacks on facilities, bases and convoys of AMISOM, of the Kenyan forces in the Gedo and Upper Jubba regions (BBC 20I7). Their civilian objectives are concentrated in the assassination of political figures, local leaders and clan leaders (elders or clan elders) who support the federal government. Part of the attacks against the civilian population have been due to reprisals by ALS for "collaboration" with foreign military forces. In this sense, there have also been retaliatory actions by AMISOM troops, the SNA or the ENDF (Ethiopian National Defense Force) when they have resumed a village or area (South and Central Somalia Security Situation, al-Shabaab Presence, and Target Groups. 20I7, 20). This is a factor that further influences the support that ALS has in certain areas as "guarantors" of "security".

Its modus operandi will be maintained through the use of car bombs, improvised explosive devices, ambushes, placement of mines and attacks against checkpoints on roads ${ }^{19}$, hotel facilities and government buildings. In general, they will continue to avoid direct confrontation against military forces and instead privilege asymmetric warfare. In particular, the regions of Kenya, along the border with Somalia, will be the most affected ${ }^{20}$.

After a period of clear withdrawal from the group, the trend suggests that ALS continues to gain ground in the south-central areas of the country ${ }^{21}$

I9 In the course of 2017 - until April - some 337 people have been killed or injured as a result of 87 explosive incidents. The civilian victims of this concept have increased by $50 \%$ since 20I5. See: Somalia: 337 civilians killed and injured in Al Shabaab attacks in 2017. (2017).

20 In April 2017 the Kenyan government was forced to decree the curfew until June 28 in the border region of Mandera and within a radius of up to $20 \mathrm{~km}$ from the Somali border, this includes the town of Mandera, Omar Jillo, Arabia, Fino, Lafey Kotulo and Elwak. See: Somalia: Kenya Extends Curfew in Border Over Al Shabaab Attacks (2017).

2I ALS has been carrying out a strong offensive in the center-south area of the country since mid-20I6. One of the factors of this advance was the withdrawal of part of the Ethiopian forces from several towns. There is no clear demarcation of which areas are under the control of ALS and the clan militias, while there are other areas in which there is a duality in the actors that control them. In the regions of this part of the country, ALS controls the main supply routes by road through checkpoints in which taxes are charged to those who are in transit. See: South and Central Somalia Security Situation, al-Shabaab Presence, and Target Groups. 2017, 6. 
in a war of constant positions against the forces of AMISON and the SNA. Therefore, the presence of ALS in south-central Somalia is consolidated, despite the actions of the AU peacekeeping troops, which only control certain areas during the day, while at night, ALS can be easily moved. The military situation is imprecise due to the advances and setbacks that occur: captures of towns and villages on several occasions, clashes between militias and rival clans to ALS for control of the regions, for example in Lover Shabelle and Jubaland.

The security situation in the capital continues to be deteriorated. Although the group can't regain control of Mogadishu and establish military bases, the city remains under constant threat for the actions of ALS. Most of the attacks are still centered in the capital. Despite being "expelled", they still have the ability to continue collecting taxes and participate in legal disputes. For its part, in the Lower Jubba region, ALS is in control of rural areas, while the Jubaland administration is "effective" in urban centers. The port of Kismayo is still controlled by AMISOM and SNA forces. In Middle Jubba, ALS controls the entire territory.

In the Hiraan region, the group is less active - subclanic confrontations prevail here. In the Bay region, the main urban centers - Baidoa - are under the control of AMISOM/SNA. In the Galguduud region, the situation is more diffuse due to the number of actors involved: Galmudug Regional Forces, Al-Shabaab and the Ahlu Sunna Wal Jama militia (ASWJ). In the Mudug area, there are clashes between ALS and local forces (South and Central Somalia Security Situation, al-Shabaab Presence, and Target Groups. 20I7, II-I6). The security situation in general does not improve, but this insecurity can't be attributed solely to the actions of ALS because other militias fighting for control of the land or for political power are also acting.

\section{Conclusion}

Spite of a certain increase of terrorism actions in bordering areas of Burkina Faso, Mali and Niger, the territorial settlement of terrorism tends to weaken in short-term, as well as its dominance and mobility in sub-Saharan Africa. It could be forecast that in 2025 will be a drastic reduction of the operating capacity and the areas of these groups if the current policies adopted by the AU continues to be implemented. Everything seems to indicate that the joint international offensive that takes place within the framework of the fight against terrorism is forcing them to carry out more covert and punctual 
actions. Thus, we are going to witness a systematic eviction of the territories that they usually occupied. This forces them to change their strategy and tactics by having to move to different forms of organization through smaller groups, not concentrated in the same territory, which significantly reduces their military strength, making them move into a situation of greater concealment, as well as regroup in lighter cells.

In terms of leadership, the systematic elimination of "emirs" at different levels affects the internal articulation of the groups due to the emergence of new figures of lower level and that would alienate the majority of those recruited from the top leaders, which could cause antagonisms within the cells/groups/organizations. The absence or frequent changes of convincing leaders to higher levels, trained to exercise power, but with little charisma, religious, psychic and political control, also exerts a marked influence on the erosion and loss of legitimacy in front of others.

The group-organization relationship and the levels of institutionalization are not determinant variables in the evolution of terrorism, because in the first case what has happened is more a declaration of principles between both structures than a real collaboration in practical terms. This is influenced by the geographic separation that exists between the areas where they operate. In the second case, the institutional weakening can contribute to a greater dispersion of the group/organization and increase the difficulty for its eradication. International terrorist organizations such as the Islamic State and Al-Qaeda continue to rival in Africa to achieve supremacy within the different groups linked or not to them.

These antagonisms will be expressed in the ideological, propagandistic and territorial domain. This will cause a constant reconfiguration of the alliances between these organizations and the groups, as well as the internal fractioning of the smaller groups. However, the relations between them tend to crack, although they do not go beyond the rhetoric. Geographic distances and anti-terrorist actions prevent greater contacts between these organizations and groups, as well as the preparation of strategies to carry out joint tactical operations of greater impact. Both organizations also face financial problems that make it difficult to extend their logistical "support" to the vast network of cells that are operating in Africa, with some of which have lost contact. In this sense, the influence of the Islamic State in the region has weakened and fails to adequately articulate a strong movement in its favor, but some cells linked to ISIS will go on its actions in the Sahel.

The fact of paying homage to organizations such as Al-Qaeda and ISIS, becomes a strategy for those leaders with less influence and who seek 
to break relations with their immediate leaders and thus achieve greater international legitimacy using the media and attracting attention to build its own leadership. According to the behavior of the different terrorist groups/ organizations, it can be observed that the relations established between them are not in a positive stage, that's why there are lower levels of cooperation among the different groups.

These groups are moving towards a recomposition of alliances and inter-terrorism influences, because of the backward they have suffered in the military and propaganda fields. Despite the few links that exist between them, they maintain an apparent degree of autonomy and military capacity to be able to continue with their political agendas through the use of force and to resist the anti-terrorist actions adopted by the world community. The maintenance of an international policy of double standards by some powers in the treatment of this problem, as well as their antagonistic positions on how to eliminate terrorism, still tend to favor the activity and resistance of these groups.

The most influential variable and, in turn, the most dependent, is the level of financing of terrorism. Its dependence obeys to the ability of each group to attract new financial resources. Once acquired, these are necessary to buy armaments, means of combats and military technology for the execution of their terrorist actions, becoming a determinant for the impulse of the group.

It is concluded that the level of self-financing and resources to be obtained by these organizations will be affected as a consequence of a major coordination process between the countries and the security mechanisms to face terrorism internationally. However, their capacities for obtaining resources through organized crime remain and will continue to be one of the main allied in supplying terrorism. In particular, the groups that operate in the trans-Saharan corridor are among those that most rely on the multiple smuggling networks, overlapping between itself. These connections do not tend to disappear, helping its existence in the near future. For that reason, one of the most important actions must be cutting all sources of financing that could encourage them to go on.

Regarding the progressive failure of Al-Qaeda's performance, the situation has been somewhat different due to its attrition for more than a decade due to the confrontation with Algerian forces, which leads the fight against terrorism in the subregion, and whose special troops and security agencies have been systematically eliminating them. Despite this, AQIM remains the organization with the greatest territorial dispersion due to the persecution of which they are subject by all national, regional and international forces. The organization tends more and more to the decentralization, when integrating 
different dispersed groups. They also lack from a fixed headquarters and have to move constantly because of the military response.

In the rest of the area, $\mathrm{BH}$ continues to be the main terrorist actor in comparison with other groups that act almost autonomously in northern Mali and Niger, and that do not structurally have the level of institutionalization reached by BH. In East Africa and the Horn area, the Somali organization ALS will represent the most potent threat to security and the leading exponent of terrorism in this part of the continent. In Somalia, ALS has its greatest dominion and control in the south-central territories of the country and will carry on with its actions against regional actors present militarily in the country. In particular, the Kenyan region of Garissa in the northeast and especially the counties of Dabaab, Wajir and Mandera are the most direct targets of their cross-border actions (Cummings R. 20I7, I).

The trends point to a decrease in the violent actions of the terrorist groups in sub-Saharan Africa, which is verified after the reduction in the number of civilian victims ${ }^{22}$, as well as the low intensity and systematic nature of the terrorist attacks. However, $\mathrm{BH}$ and ALS remain the most lethal in their respective subregions. Another feature points to a greater geographical concentration of their actions. The phenomenon of terrorism will remain affecting the African continent, directly or indirectly, through indiscriminate violence, the generation of forced migrations, and the increase and use of transnational organized crime.

\section{Recommendations}

- the governments of the region must identify the most conflictive territories to be able to concentrate in these areas all the necessary resources to combat the recruitment process of these groups;

- local development programs must continue to be implemented to counteract the recruitment capacity;

22 The civilian victims caused by BH have been reduced from II,5I9 in 2015 to 3,455 in 20I6. In the first six months of 2017 , these two groups have experienced a $29 \%$ reduction in the number of victims. ALS has caused I,83I victims in the first half of 20I7. See: Africa Center for Strategic Studies (20I7). Setbacks and Realignments: The Continuing Evolution of Militant Islamist Groups in Africa. 
- encourage greater integration of youth sectors into licit economic activities to discourage the process of radicalization and recruitment;

- redouble intelligence efforts in order to counteract the possibility of terrorist acts;

- increase levels of coordination among national security agencies, following the experiences of the Joint Multinational Task Force in the areas surrounding Lake Chad to strengthen cross-border military and counter-terrorism actions by mutual agreement;

- incorporate civil society organizations in the fight against terrorism;

- strengthen the financial mechanisms that allow the control of money laundering, illegal transactions and organized crime of which terrorist networks are financed; and

- continue with the study and dissemination of the phenomenon of terrorism to raise public awareness of its negative consequences.

\section{References}

Africa Center for Strategic Studies. 20I7. Setbacks and Realignments: The Continuing Evolution of Militant Islamist Groups in Africa. Disponível em: http://africacenter.org/6r84F54IA6/FinalDownload/DownloadId-IA6/wp-content/uploads/20I7/07/Africas-militant-islamicgroups-as-of-jun20I7.pdf

Agutu, N. 20I7. Al Shabaab top leader Hussein Mukhtar surrenders to Somali army. Disponível em: http://www.the-star.co.ke/2oI7/al-shabaableader-hussein-mukhtar-surrenders-to-somali-army

All Africa. 20I7. Somalia: 337 civilians killed and injured in Al Shabaab attacks in 2017. Disponível em: http://allafrica.com/stories/20I704I30254.html

All Africa. 20I7. Somalia: Kenya Extends Curfew in Border Over Al Shabaab Attacks. Disponível em: http://allafrica.com/stories/20I703290493. html

BBC. 20I7. Al-Shabab fighters attack Kenya military base in Somalia. Disponível em: http://www.bbc.com/news/world-africa-38768453 
Cubadebate. 20I7. UNICEF informa que grupo Boko Haram utiliza cada vez más niños como atacantes suicidas. Disponível em: http://www.cubadebate.cu/noticias/20I7/04/I2/unicef-informa-que-grupo-bokoharam-utiliza-cada-vez-mas-ninos-como-atacantes-suicidas/\#.WO${ }_{5}$ PYm6Hlit

Cummings, R. 20I7. Africa's 2017 Terrorism Outlook. Disponível em: http://www.religionandgeopolitics.org/sub-saharan-africa/africas-20I7-terrorism-outlook

Danish Immigration Service. 20I7. South and Central Somalia Security Situation, al-Shabaab Presence, and Target Groups. Disponível em: https:// www.nyidanmark.dk/NR/rdonlyres//o/South_and_Central_Somalia_Report_March_20I7.pdf

Duvillier, L. 20I6. Beyond Chibok: Over 1.3 million children uprooted by Boko Haram violence. Disponível em: https://www.unicef.org/infobycountry/files/Beyond_Chibok.pdf

Gaffey, C. 20I6. Boko Haram: 2,000 Captives Freed by Regional Force as Nigeria Launches Rehabilitation Program. Disponível em: http://www. newsweek.com/boko-haram-200o-captives-freed-regional-force-nigeria-launches-rehabilitation-57

Gaffey, C. 20I7. Boko Haram Factions 'Cannot Pay Fighters' Salaries: U.N. Report. Disponível em: http://www.newsweek.com/boko-haram-isis-nigeria-554II2

Gulf of Aden Security Review. 20I7. Disponível em: https://www.criticalthreats.org/gulf-of-aden-security-review/gulf-aden-security-review-february-27-20I7

Kriel, R., e Briana D. 20I7. Al-Shabaab faction pledges allegiance to ISIS. Disponível em: http://www.brproud.com/news/alshabaab-faction-pledges-allegiance-to-isis/254577765

Matfess, H. 20I6. Boko Haram's internal rift probably isn't good news. Here's why. Disponível em: https://www.washingtonpost.com/news/monkey-cage/wp/20i6/o8/24/boko-harams-internal-rift-probably-isntgood-news-heres-I\#comments

Nor, O., Farai S., \& James M. 20I7. Mohamed Abdullahi Farmajo elected Somalia's president. Disponível em: http://edition.cnn.com/20I7/02/08/ africa/mohamed-abdullahi-farmajo-somalia-election/ 
OAU Convention on the Prevention and Combating of Terrorism. I999. Algiers Summit, july. Disponível em: https://au.int/sites/files/treaties/ treaty-_-_oau_convention_on_the_prevention_and_combating_of_ terrorism_e.pdf

Platt, S. 20I7. Al-Shabaab update: february 2017. Disponível em: https://www. linkedin.com/pulse/al-shabaab-update-february-20I7-steven-platt

Reid, G. 20I7. Militants Rising: Islamic State's East African Ambitions. Disponível em: https://www.dailymaverick.co.za/article/20I7-oI-Io-militantsrising-islamic-states-east-african-ambitions/

Reinares, Fernando. 2005. "El terrorismo internacional". In: Panorama Estratégico 2004-2005. Ministerio de Defensa, Instituto de Estudios Estratégicos Real Instituto El Cano, p. 48.

Reuters. 20I6. AU mission says several al Shabaab commanders killed in Somalia. Available in: http://af.reuters.com/article/topNews/ idAFKCNoX2IJX

Sridharan, V. 20I7. Niger forces kill dozens of Boko Haram Islamists in counteroffensive. Available in: https://www.yahoo.com/news/niger-forceskill-dozens-boko-0438723.html

Watkinson, W. 20I6. Khalid al-Barnawi leader of jihadist Boko Haram splinter group Ansaru arrested in Nigeria. Available in: http:// www.ibtimes.co.uk/khalid-al-barnawi-leader-jihadist-boko-haram-splinter-group-ansar-arrested-nigeria-I55293I?utm_campaign=rss\&Frss $\% 2$ Fyahoous 


\section{ABSTRACT}

The Sahel-Saharan region, corresponding to West and Central Africa, has remained at the center of terrorist activism in Sub-Saharan Africa. The most affected countries remain Mali, Niger, Burkina Faso and Nigeria. However, there have been changes in the actions of several groups. On one hand, Boko Haram has decreased its level of violence, which is manifested in a reduction in the number of civilian victims, while new cells have been reactivated on the Mali border with Burkina Faso. In this particular area there has been a substantial increase of groups such as the Islamic State in the Grand Sahara and the Islamic State of West Africa, among other groups of lesser degree of organization. Because of this, security problems and foreign military presence have been maintained in all these countries. A similar situation is presented in the Horn of Africa, where Al-Shabaab (ALS) is the main group, affecting not only Somalia but also Kenya with its transborder actions. The role of the Federal Government and the AMISON troops have been insufficient to reduce or finally eliminate ALS. For those reasons, terrorism continues to be the major security challenge of the sub saharan region and it will not be mitigate in the long term.

\section{KEYWORDS}

Terrorism in Africa; Security in Africa; Foreign military presence; African Union.

Received on January 25, 2020 Accepted on February 27, 2020 